\title{
A dinâmica da presença brasileira no Índico e no Oriente. Séculos XVI-XIX ${ }^{1}$
}

\author{
Anthony John R. Russel-Wood
}

\section{Introdução}

\section{0 contexto historiográfico}

$A$ s historiografias dos impérios ultramarinos europeus compartilham 1 dois traços principais. O primeiro deles é a sua fragmentação. Em relação ao Império português, com poucas exceções, ${ }^{2}$ a historiografia sobre Portugal além-mar é limitada territorialmente (portugueses na Índia, na China, no Ceilão, em Angola, no Brasil) ou oceanicamente (o Atlântico, o Índico). Existem antecedentes históricos com relação a essa tendência. Tanto o licenciado Domingos de Abreu e Brito, em um relatório de 1591, quanto o viajante francês François Pyrard de Laval, baseado na sua residência em Salvador (1610), identificaram um forte elo entre o Brasil e a África e também uma inter-relação ibérica no Atlântico. Do outro lado, para o frade português João dos Santos e para o viajante francês Jean Mocquet, no início do século XVII a unidade do Índico era aparente. ${ }^{3}$ A historiografia do império ultramarino português tem uma segunda característica: reflete uma perspectiva predominantemente metropolitana. A presença metropolitana é inevitavelmente forte na história administrativa, nas histórias dos costumes e comportamentos e dos sistemas de crenças e valores, na história social e na história das idéias. As diásporas mercantis sobretudo são estudadas no contexto do comércio luso-brasileiro.

O propósito deste artigo é discutir a presença brasileira no Índico e no Oriente no contexto de uma história que contemple os dois hemisférios do império português. D. Luís da Cunha, por exemplo, diplomata português, num memorando confidencial de $1735 / 36$, propôs que $\mathrm{D}$. João $\mathrm{V}$ assumisse o título de imperador e passasse a residir no Rio de Janeiro. Ele viu essa mudança como um passo essencial em direção a uma melhor integração do império comercial português, cujos componentes seriam eu- 
ropeus, americanos, africanos e asiáticos, e com uma rede comercial articulada de suprimento e demanda, englobando o Atlântico, o Mar Arábico, o Oceano Índico e mares da Ásia Oriental. ${ }^{4}$ Também vou considerar o império português sem fazer referência exclusiva à metrópole. A potencialidade global do Brasil, "situado no meio do mundo", ligado à África, à Europa e à Ásia, já foi comentada pelo bispo José Joaquim da $\mathrm{Cu}$ nha de Azeredo Coutinho. ${ }^{5}$ A historiografia tradicional a respeito da vida social, política e econômica do Brasil colonial a coloca no contexto do Atlântico, quer dizer, em relação à Europa e à África. A respeito do papel desempenhado pelo Brasil em relação à Carreira da Índia, a historiografia dá ênfase a dois aspetos: primeiro, aos portos brasileiros como meros portos intermediários de escala da carreira; segundo, que estas escalas em portos brasileiros se deram predominantemente nas viagens de volta ("tornaviagem”) para a Europa. ${ }^{6}$ Enfim, enquanto há referências na historiografia a respeito da influência ou da presença oriental no Brasil, parece-me que a existência de influências ou da presença brasileira no Índico foram pouco comentadas. Nesse contexto, a minha agenda é a seguinte: primeiro, seguindo a observação do bispo Azeredo Coutinho de que o Brasil estava "com os braços estendidos, hum para a Europa, outro para a Ásia," o meu propósito é situar o Brasil no contexto marítimo do Índico e naqueles mares que se estendem até ao mar do Japão. Em segundo lugar pretendo reexaminar o papel desempenhado pelos portos brasileiros, sobretudo Salvador e Rio de Janeiro, como escalas para as naus de carreira com destino a Goa ou a Macau. Examinarei ainda a novidade que apareceu sobretudo no percurso do século XVIII e no XIX, qual seja, aquelas naus que transitaram diretamente entre portos brasileiros e aqueles portos para além do Cabo da Boa Esperança. Por fim, em quarto lugar, analisarei a presença brasileira naquelas terras desde a costa suahilí até o Extremo Oriente que faziam parte do Estado da Índia, termo referente à rede de fortalezas, feitorias, cidades, povoações e missões desde o Cabo da Boa Esperança até o Japão e as ilhas das Bandas e Molucas. Conquanto as relações entre o Brasil e o Estado da Índia e o Oriente já tenham sido objeto de várias pesquisas, destaca-se, sobretudo, o impacto comercial e artístico, além daquele resultante da introdução de flora, do Oriente sobre o Brasil. O meu propósito 
é outro: dar foco especificamente à presença brasileira além do Cabo da Boa Esperança e atribuir aos baianos e ao porto de Salvador, bem como aos cariocas e ao porto de São Sebastião do Rio de Janeiro — sobretudo no transcurso do século XVIII e começos do século XIX —, um papel mais dinâmico e um perfil mais importante do que consta da historiografia. ${ }^{7}$

O Brasil contava com pelo menos meia dúzia de baías com águas profundas, capazes de prover ancoradouros seguros para as maiores frotas da época; mas, no contexto geopolítico e comercial de meados do século XVI, a Baía de Todos os Santos era excepcional: um soberbo porto natural com $200 \mathrm{~km}$ de circunferência, uma área de $1.050 \mathrm{~km}^{2}$ de superfície e uma barra muito larga. Ainda que não fosse tão naturalmente protegida, como alguns outros portos, o tamanho fez dela "o mais conveniente lugar que há nas ditas terras do Brasil". ${ }^{8}$ Mais tarde, foram aqueles mesmos atributos físicos, sobretudo os referentes à magnífica Baía da Guanabara, que contribuíram para o enorme sucesso da Cidade de São Sebastião e para a sua importância como porto, empório, centro administrativo e capital (depois de 1763) da Colônia.

Assim, como havia sido a primeira nação européia a maximizar o potencial dos sistemas de ventos e das correntes equatoriais, dentre outras, do Atlântico, Portugal viu na Baía de Todos os Santos e na cidade recémfundada o eixo mais ocidental para o Império Atlântico português, que englobava possessões na África do Norte, na África Central e Ocidental, assim como os arquipélagos ao Norte e ao Sul do Equador. As carreiras do Atlântico para a África, para as ilhas e para o Nordeste do Brasil eram curtas e sem grandes desafios para a navegação, quando comparadas com a Carreira da Índia. O Recôncavo provia uma excelente área para a agricultura, especialmente o açúcar. Os rios e a baía garantiam acesso fácil a Salvador que, por sua vez, estava próxima das fontes de trabalho africanas. $\mathrm{Na}$ condição de porto, Salvador tornou-se importante no comércio direto Portugal-Brasil-Portugal, formando também um eixo no comércio triangular Europa-África-Brasil, e também um ponto de articulação e destino para uma rede atlântica de comércio, que excluía a Europa: Angola, São Tomé, Príncipe, Cabo Verde, Açores e Madeira. D. João III, provavelmente, não previu que Salvador se tornaria uma escala intermediária de abaste- 
cimento para navios do Estado da Índia, nem tampouco que as correntes do Brasil e das Malvinas ofereceriam às cidades portuárias brasileiras a oportunidade de assumir uma presença para além do Atlântico. ${ }^{9}$ Em termos de localização estratégica, nenhuma outra nação européia nas Américas poderia competir com as cidades portuárias do Brasil, sobretudo Salvador e Rio de Janeiro. Cada uma teve uma próspera área portuária, testemunho da sua importância como empórios, tanto para a cabotagem, como para o comércio oceânico, e cada uma podia contar com a presença de fortes, fortins, baluartes e redutos em volta das respectivas baías e áreas contíguas.

Outras cidades portuárias foram construídas ao longo dos 9.198 quilômetros da costa brasileira, mas nenhuma rivalizava com a feição imponente de Salvador. Mesmo na década de 1560 houve discussão em Portugal sobre a importância relativa do Estado da Índia e dos interesses portugueses no Atlântico - e ao longo do século XVII o Estado da Índia entrava em declínio. Observando a mudança da importância da Índia portuguesa para o Brasil, um frade franciscano em Salvador escreveu em 1702: "A Índia Oriental há muitos anos que por pecados e injustiças já não é Índia: o Brasil, pela cana, pelos bizalhos de diamantes que embarca em milhares de caixas todos os anos, é a verdadeira Índia e Mina dos portugueses". ${ }^{10}$ Por volta de 1700, Salvador era a mais importante cidade do ultramar português, o principal exportador de açúcar e fumo para a Europa, de uma importância sem par no comércio para a África Central, e capital da colônia mais rica de Portugal. No decurso da primeira metade do século XVIII, foi sofrendo um declínio sempre maior diante das riquezas do Rio de Janeiro, que respondeu melhor às novas prioridades políticas e às realidades econômicas e comerciais. O Rio de Janeiro se tornou o porto mais indicado para a exportação de ouro e diamantes das capitanias recém-criadas no interior. Tornou-se o porto mais favorecido pela exportação e importação de mercadorias e importação de escravos, constituindo-se, assim, uma classe mercantil de grande influência política, status social e recursos financeiros. Estrategicamente, o Rio de Janeiro estava mais próximo das terras contestadas entre Portugal e Espanha no Rio da Prata. Esta reorientação econômica do Brasil colônia, desde o Nordeste para o Sudeste, exigiu novas medidas administrativas. Transferiu-se a capital de Salvador para o Rio de Ja- 
neiro em 1763. Mesmo assim, a importância da própria Baía de Todos os Santos e das facilidades portuárias continuaram inegáveis, e a cidade do Salvador continuou a desempenhar um papel importante em relação às novas configurações da Carreira da Índia.

\section{Uma presença brasileira além do Cabo de Boa Esperança}

\section{A governança civil}

Ainda que durante o período das capitanias a da Bahia tenha sido um fracasso quando comparada à de Pernambuco e a de São Vicente, o estabelecimento da capital em Salvador (1549) deu-lhe instantâneo reconhecimento como centro administrativo da colônia, embora no início do século XVII alguns governadores-gerais tivessem preferido residir em Pernambuco e assim desfrutar da vida social de Olinda. Não apenas Salvador foi o centro do governo real até 1763, e a sede do único vice-reinado no mundo Atlântico português, mas também a sede da única Relação no Brasil, até 1751, e do único bispado (1551-1676) e mais tarde (1676) arcebispado no Brasil. É bem sabido que Salvador desempenhou o papel principal na administração secular e eclesiástica dentro do Brasil. Menos conhecido é que esse papel administrativo tenha ultrapassado os limites territoriais do Brasil. Examinaremos essa afirmação em relação ao posto de governador-geral/vice-rei, à Relação, aos assuntos militares e às carreiras dos altos funcionários da Coroa.

Embora o governador-geral ou vice-rei, sendo o mais importante representante na colônia da Coroa, tenha desempenhado um papel para além da extensão territorial do Brasil em relação à governança e defesa dos territórios portugueses na África e no Golfo de Benim, existem poucas refêrencias à sua participação em decisões referentes ao Estado da Índia. É escassa a correspondência entre vice-reis ou governadores com sede em Goa e em Salvador e, posteriormente, no Rio de Janeiro. Esta falta é um indicativo da bifurcação administrativa e da governança do império ultramarino português entre o Estado da Índia e o Estado do Brasil. O mais prestigioso e eficiente ramo do governo, o judiciário, também refletiu esta fragmentação de jurisdições. O Regimento para a governança da Relação em Goa 
tem a data de 8 de abril de 1544. Funcionou uma Relação em Salvador entre $1609-1626$ e de 1654 até ao século XIX. Uma segunda Relação começou a funcionar no Rio de Janeiro em 1751. ${ }^{11}$ Nos fins do século XVII, a Relação de Goa estava experimentando problemas no seu funcionamento, atribuíveis em parte à falta de experiência dos desembargadores. Recomendou-se que a Relação de Goa, apesar da sua antecedência, devia adotar o Regimento da Relação de Salvador, documento exemplar pela sua conformidade com as leis do reino. ${ }^{12}$

O Brasil colonial nunca teve o forte caráter militar que foi marcante no Estado da Índia. Vice-reis/governadores-gerais em Salvador eram responsáveis pela defesa do Brasil. Isso incluía o estabelecimento de lugares de defesa, equipamento de guarnições, regulamentação das tropas de linha e o aumento das milícias e auxiliares. Salvador era também base para operações militares no Atlântico Sul. No auge dos ataques ao Estado da Índia, no século XVII, sugeriu-se que se enviassem reforços do Brasil; porém, tais sugestôes eram raramente atendidas e, quando o eram, de modo inadequado. As tentativas de um vice-rei/governador-geral de manter regimentos em Salvador além do efetivo eram frustradas por deserções, falta de vontade e evasão. Na década de 1690 houve várias consultas do Conselho Ultramarino a respeito do Brasil como fonte potencial de soldados para suprir as guarnições portuguesas na Índia. Parece mesmo que houve uma ordem régia neste sentido. Pressionado pela comunidade mercantil de Salvador que esperava que fosse aprovado o comércio franco entre o Brasil e Moçambique e a Índia, em 1699 o governador-geral em Salvador enviou para Lisboa uma proposta que enfatizava as alegadas vantagens financeiras para a Coroa caso mandasse soldados diretamente do Brasil para a Índia. ${ }^{13}$ Com certeza houve participação baiana - mesmo sendo às vezes constrangida - e soldados e oficiais de origem brasileira serviram na Índia no percurso do século XVIII. Um edital régio de 1748, requerendo alistamento voluntário de 1.500 soldados, para a guarnição militar da Índia, foi publicado em Salvador. ${ }^{14}$ Há notícias de soldados passando por Salvador, de volta da Índia a caminho de Portugal; contudo, há dúvidas se uma campanha para alistamento em Salvador teria reunido muitos voluntários para servir na Índia. Mesmo assim, na década de 1780, soldados de "guarnição de 
carreira" foram remetidos de Salvador para Moçambique, criando um problema para o governador daquele território que não contava com recursos financeiros para pagar os soldos de tais soldados. ${ }^{15}$

Em 1786 o governador da ilha de Moçambique acusou a chegada de dois "soldados incorrigíveis" mandados pelo governador de Salvador. Também na década de 1780, vários soldados do regimento de infantaria em Salvador foram mandados para Índia como punição por sua má conduta. Em 1789, foram embarcados em Salvador, na nau Nossa Senhora da Conceição e Santo Antônio, três soldados degredados para a Índia pelos seus crimes: dois do segundo regimento de infantaria da guarnição de Salvador e um do regimento de infantaria de Pernambuco. ${ }^{16}$

Uma dimensão muito diferente da projeção brasileira no império português diz respeito aos movimentos que caracterizaram as carreiras dos altos funcionários da Coroa. Em tais movimentos de carreira, o padrão predominante era o de oficiais que haviam servido na África ou na Ásia serem então nomeados para cargos no Brasil, com uma subseqüente nova nomeação ou uma aposentadoria em Portugal. Mas havia alguns poucos exemplos onde altos representantes da Coroa transferiam-se de Salvador para Goa. ${ }^{17}$ Estes incluíram os seguintes governadores-gerais/vice-reis que serviram em Salvador: D. Vasco Mascarenhas, governador-geral interino do Brasil (1639-40), vice-rei na Índia (1652-53) e vice-rei em Salvador (1663-67); Antônio Luís Gonçalves da Câmara Coutinho, governador-geral do Brasil (1690-94) e vice-rei na Índia (1698-1701); D. Rodrigo da Costa, governador-geral no Brasil (1702-05) e vice-rei na Índia (1707-12); D. Pedro de Almeida, terceiro Conde de Assumar, e mais tarde Marquês de Castello-Novo e de Alorna, tendo sido governador da capitania de São Paulo e Minas Gerais (1717-21), além de vice-rei do Estado da Índia, onde distinguiu-se pelos seus talentos administrativos e militares e pelo seu sucesso em batalha contra os marathis, culminando na captura da fortaleza de Alorna em 1746. Antes de ser nomeado e tomar posse (1816) com o 49ํㅡㅇ vice-rei e capitão-geral da Índia, D. Diogo de Sousa, primeiro Conde do Rio Pardo, foi governador e capitão-geral em Moçambique (1793-98), governador e capitão-geral da capitania do Maranhão e Piauí (1798) e o primeiro capitão-geral da capitania do Rio Grande de São Pedro (1807- 
14). Nenhum desses homens nasceu no Brasil. Mesmo assim, o mero fato de que Portugal tivesse vice-reinados concomitantemente na América e na Ásia, fez dele um caso único dentre os impérios ultramarinos europeus. Por outro lado, seria fascinante conhecer mais acerca do impacto e, se foi esse o caso, da experiência brasileira sobre os governadores-gerais que mais tarde serviram como vice-reis na Índia. Foi o grande historiador baiano, Sebastião da Rocha Pitta, que comentou com grande orgulho sobre "As pessoas naturaes do Brasil, que exerceram dignidades e governos ecclesiásticos e seculares na patria e fóra d'ella". Com três exceçôes, tais cargos estavam no Brasil, no Maranhão, em Angola, em Cabo Verde, em São Tomé e em Lisboa, como conselheiros ultramarinos, desembargadores da Casa de Suplicação em Lisboa ou da Relação do Porto e provedores e vedores da fazenda real. As três exceçôes que ocuparam cargos administrativos no Estado da Índia foram os seguintes brasileiros: o Doutor Pedro Pinheiro e o Doutor Agostinho de Azevedo Monteiro, que foram desembargadores na Relação em Goa; e Tomé de Sousa Correia, castelão de Moçambique. ${ }^{18}$ As experiências destes vice-reis, governadores, juízes e administradores em dois hemisférios merecem a nossa atenção pelo potencial que oferecem ao estudioso que se interessa pela história das mentalidades e das idéias no império ultramarino português, e, especificamente, pela história da contribuição brasileira à governança do Estado da Índia.

\section{Os padres como pontes entre dois hemisférios}

Já no século XVI, os padres jesuítas na Ásia mandaram cartas para os seus correligionários no Brasil revelando ligações de ordem religiosa entre o Brasil e a Índia. Houve vários exemplos de padres jesuítas, já com experiência na Índia, que desembarcaram em Salvador nas viagens de volta a Portugal. O mais célebre foi o Pe. João de Brito que embarcou em Goa em dezembro de 1686 com destino a Lisboa e fez escala em Salvador em 1687. Em 1696 outro jesuíta, Pe. João da Costa, também desembarcou em Salvador. Estes incentivaram padres jesuítas brasileiros a viajarem para a Índia em missão evangelizadora, criando assim uma presença brasileira no Índico. Um deles foi o baiano Francisco de Sousa, S. J., nascido na Ilha de Itaparica em 1649. Ganhou grande fama como autor do livro Oriente conquistado a 
Jesus pelos padres da Companhia de Jesus da Provincia de Goa (Lisboa, 1710). Morreu em Goa em 1712. Dois padres jesuítas, também filhos da Bahia, o Pe. José Agostinho e o Pe. José Teotônio, foram martirizados em Goa em 1760. Sem dúvida houve outros exemplos de uma presença brasileira de religiosos no Índico e no Oriente. Mais uma vez surge a pergunta: será que esses padres nascidos no Brasil trouxeram para o Oriente uma perspectiva distinta daquela dos seus contemporâneos de nascimento europeu? No caso de Luís de Góis - português de nascimento que se tornou padre jesuíta em Goa em 1562, e que lá morreu aos 63 anos em 1567, e a quem Damião de Góis atribuiu a introdução do fumo em Portugal —, parece que a sua residência em São Vicente e as suas experiências como senhor do engenho de Madre de Deus criaram nele uma preocupação espiritual com a evangelização dos índios, e mais tarde o incentivou a tomar os votos de obediência como jesuíta, cumprindo suas ações apostólicas como confessor e missionário em Divar e Chorão. ${ }^{19}$

Só encontrei um exemplo de um brasileiro nomeado para um alto posto eclesiástico no Oriente. Foi D. Fr. Francisco da Assunção e Brito, natural do Bispado de Mariana, nomeado para ser bispo de Pernambuco. Depois de confirmado em 15 de março de 1772, tomou posse por procuração em 5 de dezembro de 1773 . Nomeado arcebispo de Goa, renunciou ao bispado em 1 de janeiro de $1783 .{ }^{20}$

\section{No serviço de Mamón: o Brasil e a Carreira da Índia}

Segundo a historiografia, com poucas exceçôes, a presença comercial do Brasil limita-se ao Atlântico. Um aspecto que tem merecido a atenção de historiadores é o papel dos portos brasileiros, sobretudo o de Salvador, como ponto de escala na Carreira da Índia. Segundo esses autores, tais escalas foram muito atraentes para os capitães, oficiais e marinheiros e para aquelas pessoas voltando da Índia para Lisboa que viam em Salvador uma boa chance para vender/trocar produtos asiáticos por açúcar, fumo e outros produtos brasileiros, num comércio predominantemente ilegal e clandestino. Em resumo, para além do contexto comercial do Atlântico, Salvador tem sido retratada como porto para descarga, mais do que para carregamento de mercadorias. Alguns exemplos poderão corrigir essa visão, 
situando Salvador como um participante ativo no comércio multioceânico.

A participação da Bahia no comércio além do Atlântico teve várias dimensões. Vamos examimar quatro configurações comerciais que servem para ilustrar como o Brasil podia se aproveitar da Carreira da Índia para conseguir que os seus produtos chegassem ao Índico e achassem mercado na Índia e no Extremo Oriente.

(a) Uma manifestou-se através da exportação para Lisboa de produtos brasileiros e do reembarque desses produtos em embarcações integrando a Carreira da Índia. Fumo, mas só o da melhor qualidade, foi o produto baiano mais procurado na Ásia. A cidade de Salvador dispunha de uma posição incomparável para tirar vantagem dessa oportunidade. $\mathrm{O}$ cultivo do fumo já estava se desenvolvendo no Recôncavo desde a década de 1570 . Embora fosse cultivado por quase todo o Brasil (Maranhão, Pará, Pernambuco, Alagoas, Sergipe d'El Rei, Rio de Janeiro, São Paulo e Minas Gerais), a Bahia dominava a produção brasileira (e mundial) de fumo, desde a segunda década do século XVII até 1815. A maior parte do fumo exportado de Salvador para Lisboa era reexportada para venda na Europa (Itália, Alemanha do Norte, Espanha, por exemplo) e na Índia.

O fumo chegava ao Oriente por duas vias: por recarregamento em Lisboa e por via direta de Salvador para Goa. Já na década de 1620, o produto baiano era transportado para Lisboa para ser transformado em pó. O monopólio régio do fumo foi estabelecido em Lisboa entre 1624 e os primeiros anos da década de 1630 e, em Goa, no ano de 1624. O comércio do fumo enviado para a Índia se tornou altamente lucrativo. A cota régia anual de exportação de fumo para a Índia aumentou de 4.000 arrobas para 6.000 arrobas na década de 1790 . A Junta da Administração do Tabaco foi criada em 1674 em Lisboa. Em 1680 uma Junta da Administração do Estanco Real do Tabaco foi estabelecido em Goa para regular todos os aspectos, sobretudo fiscais e comerciais, do fumo. ${ }^{21}$ Em Goa e nas áreas vizinhas de Bardés e Salsete, o contrato era arrematado a negociantes locais com arrendamentos trienais, desde a década de 1620 até o século XIX. Este contrato foi muito contestado. Em fins do século XVII, o fumo baiano foi o produto de exportação mais lucrativo no comércio de Lisboa para a Ásia. 
Depois que Bombaim foi cedida à Inglaterra, os ingleses passaram a comprar fumo em Lisboa para vendê-lo na Índia. O fumo baiano foi também transportado para Macau, onde um Estanco do Tabaco foi estabelecido. Daí, foi disseminado pela China, sob a dinastia Qing (Manchu). Na China, havia preferência pela folha aberta, ao invés de rolos de fumo, assim como havia mercado para rapé. ${ }^{22}$

(b) Na segunda metade do século XVII, e de modo crescente no século XVIII, as naus da Carreira da Índia, em torna-viagem para Lisboa, aportaram em Salvador. Provisões de 1672 e 1692 legalizaram e até mesmo encorajaram paradas em Salvador. Uma resolução régia de 1734 autorizou a venda na Bahia de mercadorias de proveniência asiática sob a condição de serem pagas as devidas taxas alfandegárias, e tal resolução foi confirmada por um alvará de 1783. Mercadorias de origem asiática tanto eram vendidas em Salvador quanto reembarcadas com destino a Costa da Mina e Angola para serem trocadas por escravos ou, ainda, com destino ao Rio da Prata para serem trocadas por prata.

Paralelamente, na segunda metade do século XVII, e mais intensamente ao longo do XVIII, as naus da Carreira da Índia com destino à Índia também aportaram em Salvador. Aí eram carregadas de fumo (em pó e em folha), açúcar, cereais, cachaça, peles, farinha de mandioca, alimentos, madeiras, coquilhos, pau-brasil e ouro em barras. Goa era o destino principal, sendo ainda várias mercadorias enviadas para Macau. ${ }^{23} \mathrm{~A}$ historiadora indiana Celsa Pinto observou que entre os anos de 1798 e 1820 foram os negociantes luso-brasileiros os principais fornecedores de ouro e prata para Coromandel e Bengala. ${ }^{24}$

Mesmo sendo Lisboa o porto de origem de tais naus e sendo Salvador apenas um ponto de escala, este comércio foi uma novidade, pois os produtos brasileiros estavam sendo exportados de um porto brasileiro diretamente para Goa. Nas décadas de 1770 e 1780, principalmente, há numerosas referências a consignações de fumo em rolos, em pó e em folha aberta, que eram carregadas em Salvador, em embarcaçóes vindas de Lisboa, com destino a Goa. Estas embarcaçôes com freqüência transportavam tropas para a Índia e fizeram escala em Salvador em função da alta incidência de doença e mortalidade. ${ }^{25}$ A Mesa de Inspeção em Salvador emitiu ofíci- 
os para o carregamento de fumo em tais embarcações. Governadores em Salvador - especialmente o Marquês de Valença e D. Rodrigo de Meneses - estavam sempre às voltas com solicitaçôes incessantes do secretário de Estado em Queluz, para providenciarem cargas de fumo em folha, cuja compra e frete seriam da responsabilidade da Fazenda Real, e para atuarem fortemente no combate ao contrabando. ${ }^{26}$

(c) No século XVIII, a Carreira da Índia assumiu uma nova dimensão: o comércio direto entre o Brasil e a Ásia. Já na década de 1690 a comunidade mercantil de Salvador exerceu pressão sobre o governador-geral neste sentido. De fato, em 1699, mandou para Lisboa uma proposta sugerindo que fossem iniciadas relações comerciais diretas entre Salvador, Pernambuco e Rio de Janeiro, além de Moçambique e Goa e outros portos do Estado da Índia. Já em carta de 28 de novembro de 1699, o vice-rei de Goa informou o rei de que não devia haver saída em Moçambique para mercadorias exportadas de Salvador para aquele porto, e achou desvantajoso para a fazenda real permitir livre comércio de navios entre Salvador e a Pérsia. Assim, não houve surpresa quando a proposta do governador-geral foi rejeitada pela Junta de Tabaco, em 16 de fevereiro de 1700, cuja preferência foi que todo o comércio fosse feito via Lisboa, como foi o costume, e pela Casa da Índia, em 20 de fevereiro de 1700, ambas com sede em Lisboa. A Casa da Índia achou que os produtos sugeridos pelos mercadores baianos para exportação para a Índia — açúcar, fumo, gabarito, jacarandá e pau violeta - eram supérfluos e impróprios. Mas a reação em Goa foi de outro teor. A noção de comércio direto por particulares entre o Brasil e a Índia foi calorosamente acolhida em Goa, cujas pessoas principais acharam que a novidade de tal comércio direto podia resultar num renascimento econômico e num crescimento na população, além de contribuir para a fazenda real pelas taxas alfandegárias. O próprio rei foi contra a proposta de comércio direto entre Brasil e Moçambique, mas favorável ao comércio direto Brasil-Índia. A proposta também foi rejeitada pela maioria das pessoas consultadas pelo vice-rei de Goa e pelos participantes de uma reunião convocada em Goa em 10 de novembro de 1700. Os mercadores baianos não desistiram. No século XVIII, agiram coletivamente, cresceram em seus números e começaram a exigir para si maior influência e poder político. $\mathrm{O}$ 
fato de uma companhia de comércio pombalina não ser estabelecida em Salvador deve ser atribuído à oposição por parte da comunidade mercantil local. Já na segunda metade do século XVIII existiam comunidades de mercadores nos maiores portos brasileiros interessadas no comércio de cabotagem, no comércio Atlântico e no comércio interoceânico de longa distância. Cada comunidade teve a sua própria estrutura e hierarquia social e econômica. ${ }^{27}$

No percurso do século XVIII verificou-se a introdução de embarcações navegando da Ásia para o Brasil, mas retornando à Ásia, ao invés de continuarem até Portugal. Suas cargas eram vendidas em Salvador ou transferidas para outros navios, a fim de seguirem para Portugal, ou África. Em Salvador, essas embarcações eram carregadas com produtos baianos e também com produtos chegados de Portugal. Mas as próprias embarcações não passaram além de Salvador. ${ }^{28} \mathrm{O}$ monopólio português do fumo terminou em 1775, o que incentivou indivíduos a comerciarem diretamente do Brasil com a Índia. Os navios procedentes de Salvador deviam fazer escala no Rio de Janeiro para serem vistoriados antes de continuarem a viagem para Goa. ${ }^{29}$ Assim, além das cargas subvencionadas pela fazenda real, desde a década de 1760 houve intenso comércio de fumo entre particulares, sobretudo de fumo em folha, de Salvador para Goa. Os governadores, tanto em Salvador como em Goa, foram exortados pelo rei e pelo secretário de estado em Lisboa a tomarem providências para evitar as fraudes e abusos cometidos pelos mercadores baianos, como por exemplo o de mandarem folhas de qualidade inferior e mesmo de péssima qualidade ou danificadas, além de inadequadamente empacotadas. ${ }^{30} \mathrm{O}$ que nos interessa sobretudo aqui é a exportação do fumo brasileiro para o Oriente, mas não devemos deixar de fazer referência ao fato de o Brasil abastecer Goa com uma enorme variedade de alimentos, inclusive gengibre, salsicha, queijo e açúcar. $^{31}$

Salvador, entretanto, assumiu novo papel sancionado pela Coroa: além de ser o porto de chegada e de partida para embarcações na rota LisboaSalvador-Lisboa, e para aquelas diretamente engajadas no comércio Salvador África-Salvador, e além de se constituir em um eixo no comércio triangular Europa-África-Brasil-África, a cidade tornou-se parte de outra rede 
interoceânica de comércio, que ligava Ásia-Brasil-África (Luanda, Benguela) em todas as combinações possíveis. A situação mudou completamente depois da transferência da corte real para o Rio de Janeiro. A partir de 1808 foi autorizado o comércio direto do Brasil para Índia e para Macau, e naus brasileiras se aproveitaram dessa oportunidade para viajar diretamente do Rio de Janeiro ou de Salvador para Macau, sem fazer escala em Goa, onde os chineses procuraram avidamente o fumo. Os armadores brasileiros enfrentaram uma concorrência da parte da Companhia Oriental Inglesa e de comerciantes portugueses, e foram os armadores do Rio, mais do que os seus colegas em Salvador, que prevaleceram neste novo ambiente comercial.

Essas considerações sobre as ligações comercias diretas entre Salvador e São Sebastiāo do Rio de Janeiro e os portos do Estado da Índia exigem algumas observações a respeito do comércio intercolonial. O Índico e a Ásia fornecem numerosos exemplos de comércio intercolonial dentro e fora do Estado da Índia. Tal comércio foi atribuível à iniciativa empresarial de particulares: a própria Coroa não era um parceiro ativo, não extraía plenos benefícios tributários e nenhum porto português estava envolvido, sendo que a receita permanecia majoritariamente na Ásia. No Atlântico sob influência portuguesa, houve menos oportunidades. O comércio SalvadorCosta da Mina/Angola-Salvador constituiu um exemplo excepcional de como comerciantes coloniais estabeleceram e sustentaram seus mercados, sem se incomodar com interesses metropolitanos. A historiadora Celsa Pinto observou que enquanto nas últimas décadas do século XVII e durante o século XVIII houve plenas manifestaçôes da decadência do Estado da Índia como entidade institucional, militar, administrativa e comercial sob auspícios reais, paralelamente criaram-se magníficas oportunidades para empreiteiros particulares portugueses ganharem fortunas no comércio intraasiático. Mesmo Portugal e o próprio Estado da Índia conseguiram tirar algum proveito desse clima de oportunidades e favorável a empreendimentos. ${ }^{32} \mathrm{O}$ contexto brasileiro foi totalmente distinto. No século XVIII o Brasil passsou por uma fase de expansão sobretudo no setor comercial, estimulado em grande parte pelo acesso às riquezas derivadas diretamente e indiretamente dos descobrimentos de jazidas auríferas e de diamantes. Criaram- 
se nos portos brasileiros comunidades de mercadores de curto e de longo percurso, como consta da lista compilada em 1759 pelo engenheiro militar José António Caldas, para Salvador. No decorrer do século, a descoberta de ouro e de diamantes estimulou um maior comércio interno e internacional, bem como a emergência de poderosos grupos de mercadores. Daí o potencial para a acumulação de capitais no Brasil, derivados de atividades comerciais e agrícolas, e também no setor de exportações, o que levou a uma diminuição resultando na dependência de financistas metropolitanos para empréstimos. ${ }^{33}$

(d) Até aqui a participação comercial da Bahia em redes comerciais tem estado dentro do parâmetro institucional do comércio sancionado pela Coroa. Em Salvador, não menos que em outras cidades portuárias do Brasil, havia uma bem desenvolvida prática de evasão. ${ }^{34}$ Isto envolvia participação em contrabando para dentro e fora do Império português. Salvador e a costa baiana ofereciam amplas oportunidades para o contrabando de ouro para Portugal, para a Europa (especialmente Inglaterra, diretamente, ou através do Falmouth Packet de Lisboa ), para a Costa da Mina, para a África Central, e para a Índia. ${ }^{35}$ Seria de se esperar que tivesse havido participação baiana nesta exportação de ouro e prata para a Índia, seja de ouro brasileiro, seja de prata oriunda da América Espanhola. Descobertas de ouro na Bahia, na primeira metade do século XVIII, à montante dos rios navegáveis, até o mar, aumentaram essas oportunidades. $\mathrm{O}$ ouro, assim como o fumo, foi levado para a Índia por embarcaçōes francesas e inglesas, tocando Salvador ou, no caso do ouro, por navios ingleses, em Lisboa, em rota para a Ásia. Salvador também se envolveu no comércio ilegal de açúcar e escravos para o Rio da Prata. Salvador e São Sebastião do Rio de Janeiro foram integradas nas principais rotas de ida e volta da África e Europa, as quais se ligaram dentro de diásporas mercantis envolvendo Europa, África e América do Norte, as ilhas do Caribe, estendendo-se para além do Atlântico e pelo Mar Arábico, Oceano Índico e mares da Indonésia e do Extremo Oriente. O historiador brasileiro José Jobson de Arruda apontou um paradoxo inerente a esse comércio: para estimular a produção colonial, a Metrópole foi compelida a afrouxar restriçôes no comércio intercolonial, do que resultou a perda de certos setores do comércio além-mar e dos direitos alfandegários deles derivados. ${ }^{36}$ 


\section{A Ilha de Moçambique: uma comunidade luso-brasileira no Índico}

Moçambique nos dá um exemplo de uma comunidade comercial brasileira sediada no Índico. Ainda no século XVI, naus rumando de Goa para Portugal paravam em portos brasileiros, onde desembarcavam escravos provenientes da África Oriental. Entretanto, naquela época, maiores números de escravos eram provavelmente trazidos de Moçambique pelas naus em viagem para a Índia. Durante o século XVII, a ocupação holandesa de Mouri (1612), São Jorge da Mina (1638) e Angola e Benguela (1644-8) estimulou o tráfico de escravos de Moçambique e Quelimane para o Rio de Janeiro. Mesmo assim, a política da Coroa continuou a considerar Angola como a fonte preferida para fornecer mão-de-obra para o Brasil. Escravos provindos da África Oriental continuaram a ser transportados esporadicamente para portos brasileiros. No século XVIII, considerouse, novamente, o potencial da África Oriental como fonte de escravos, proposta apoiada pelo Conde de Assumar (governador de São Paulo e Minas Gerais, 1717-21) e pelo próprio vice-rei do Brasil, o Conde de Sabugosa, que já fora vice-rei de Goa (1712-7). Contudo, o tempo de transporte mais longo e o custo mais elevado, em relação aos escravos da África Central, junto à baixa reputação que os escravos da África Oriental tinham no Brasil, fez com que o assunto fosse engavetado. ${ }^{37}$ A situação mudou em 1752, quando Moçambique ganhou autonomia administrativa, não mais sendo subordinada ao vice-rei/governador-geral em Goa. ${ }^{38} \mathrm{Um}$ componentechave da política econômica pombalina foi a intensificação da produção agrícola no Brasil. Inaugurou companhias privilegiadas para o Maranhão e Pará, Pernambuco e Paraíba. Neste contexto, Pombal viu o tráfico de escravos Moçambique-Brasil como instrumento para levar mais escravos para o Brasil, aumentar a produção agrícola e também revitalizar a moribunda economia moçambicana. Pombal favoreceu os comerciantes metropolitanos em detrimento dos colonos brasileiros. Assim, por alvará régio de 1765 , comerciantes portugueses foram autorizados a enviar embarcações e suas cargas para a ilha de Moçambique e portos em terra firme, carregar escravos e transportá-los para o Brasil. Apenas em 1769, embarca- 
ções brasileiras foram autorizadas a comercializar livremente com os portos de Moçambique, mas já houve ocasiōes na década de 1760 em que naus do Brasil entraram em portos da África Oriental. Um alvará de 1772 proibiu naus brasileiras de entrarem no Índico, permitindo apenas o comércio com Moçambique - e esta proibição ficou efetiva até $1808 .^{39}$

Capitães-gerais em Moçambique desempenharam papel decisivo nesta iniciativa. Tal foi o caso de Baltasar Manuel Pereira do Lago (1765-79), eficaz administrador que cuidou da defesa da colônia, e que promoveu o comércio de escravos e de marfim. Encorajou negociantes portugueses e brasileiros a despachar escravos para as ilhas Mascarenhas; também estimulou comerciantes da Bahia e do Rio de Janeiro a verem Moçambique como uma fonte de escravos. O vice-rei de Goa, o Conde de Ega, protestou veementemente contra propostas para estabelecer portos da África Oriental como zona franca para o comércio. Na década de 1790 o governador-geral da África Oriental portuguesa, D. Diogo de Sousa Coutinho, mostrou-se favorável a um comércio entre Moçambique e Brasil, para o qual a aprovação real foi dada em 1795 . Um decreto de 1811 o estendeu a portos portugueses subordinados na África portuguesa oriental. A transferência da Corte Real para o Brasil, as pressões abolicionistas da Inglaterra sobre Portugal resultantes das restrições no comércio atlântico, bem como o reconhecimento de Portugal (1825) da independência brasileira, tudo favoreceu a mudança da África Ocidental e Central para a África Oriental, como fonte de escravos para o Brasil, onde havia crescente demanda por mão-de-obra nas plantações de café. ${ }^{40}$ Salvador — juntamente com Rio de Janeiro, Pernambuco, Maranhão e Pará — participou desse comércio levando cargas de açúcar, cachaça, alimentos, fumo, armas e pólvora e madeira para construção naval. ${ }^{41}$ No caso baiano houve vários exemplos de experiência prévia. Já durante o vice-reinado do Conde de Alvor em Goa (1681-1686) houve notícias de um navio oriundo de Salvador que aportou em Quelimane mas, não encontrando mercado para a venda de sua carga, sofreu grandes prejuízos financeiros. Por ordem régia de 11 de fevereiro de 1700, o rei mandou o governador-geral em Salvador despachar uma embarcação para Moçambique, mas esclareceu que a ação não devia ser considerada como abertura de precedente para o livre comércio. ${ }^{42}$ 
Nessa nova onda de interesse da parte de comerciantes brasileiros, é difícil avaliar o grau da participação baiana num comércio que era dominado por mercadores do Rio de Janeiro e que estabeleceram casas de negócio em Moçambique. Mas, já em 1761, duas embarcações de Salvador rumaram para Moçambique. A revitalização da indústria açucareira no Nordeste também havia aumentado a demanda de escravos. A Bahia estava em boas condições para prover açúcar e cachaça, assim como madeira, para a construção de navios, e cordame, para esse comércio. Uma notícia de 1773 faz referência a comerciantes de Salvador e do Rio de Janeiro, participando no comércio de Moçambique, estabelecendo casas de negócio e se engajando no comércio escravo, não apenas voltado para os portos brasileiros, mas também despachando navios para as Ilhas Mascarenhas, e carregando marfim, ouro, búzios e escravos para a Índia. Esse seria outro exemplo de uma presença brasileira no comércio entre o sudoeste da África e a Índia oriental. Tais negociantes poderiam ter trazido de volta para Salvador paupreto e tecidos da Índia e Bengala, e escravos, marfim, ouro e buzios. ${ }^{43}$

No Império utramarino português, a dispersão comercial provia o contexto em que comunidades de portugueses se estabelecessem nas periferias, ou mesmo fora do Império. ${ }^{44}$ É bem documentada a presença de comunidades de negociantes e mercadores baianos nos portos do Golfo de Benim. ${ }^{45}$ Com relação à costa Suahilí, e a Moçambique, em particular, o ouvidor de Moçambique comentou num memorando de 1773 que foi o comércio que estimulou brasileiros a estabelecerem casas de comércio e a comerciar não apenas com portos brasileiros, mas também para as ilhas Mascarenhas e para a Índia portuguesa. Provavelmente, alguns desses comerciantes passavam parte do tempo em Moçambique; outra, no Brasil; mas outros, provavelmente, fixaram-se em Moçambique. Parece que, até o presente, não se realizou pesquisa aprofundada sobre a presença de comerciantes brasileiros residentes em Moçambique que era uma encruzilhada entre o Índico e o Atlântico e que, depois de 1808, teve ligações mais fortes com o Rio de Janeiro do que com Lisboa. Além deste aspecto comercial, Moçambique foi ponto de encontro de brasileiros e franceses e, como observou José Capela, do ponto de vista ideológico, "Moçambique não ficou completamente imune à penetração das novas idéias em curso, quer a partir da França quer provenientes do Brasil”. ${ }^{46}$ 


\section{As naus: veículos vinculando o Ocidente e o Oriente}

Sob o amplo rótulo de uma projeção comercial da Bahia, temos examinado diásporas comerciais e o papel da Bahia no engajamento do comércio legal e ilegal. Um componente instrumental de tal comércio foram as embarcações e, por isso, uma breve referência deve ser feita à construção marítima. A Baía de Todos os Santos era um ponto de congregação de embarcações da Carreira da Índia e das carreiras africanas e européias, além de um ponto central para o comércio de cabotagem. Foi também um centro para a construção de caravelas, bergantins e mesmo galeões e naus. Amaral Lapa calcula que cerca de 30 embarcaçóes para alto-mar foram construídas na Bahia, no período de 1665 e 1822; dessas, pelo menos 14 navegaram em rotas para a Ásia, e outras podem ter sido integradas em algumas partes da Carreira da Índia. ${ }^{47}$ Em resumo, produtos baianos eram transportados para o Índico em embarcações construídas em Salvador.

\section{A aventura das plantas}

Em relação a outro aspecto concernente à projeção da Bahia no Índico e no Oriente, a minha hipótese é mais tênue, mas seguirei duas linhas de investigação: a alimentação e os costumes. Sabe-se bem que o Brasil foi o ponto de disseminação de plantas americanas além-mar. No caso da disseminação na Europa, a Espanha ultrapassou o Brasil, mas há ampla evidência de que plantas nativas do Brasil, e das Américas em geral, foram transportadas pelos portugueses, nos séculos XVI e XVII, para a África Ocidental, Central e Oriental, para a Índia e para a China: elas incluíam o milho, a mandioca, a batata-doce, o amendoim, o abacaxi e a abóbora. A contribuição específica da Bahia não foi registrada, mas seria muito provável que em relação a São Tomé e Príncipe e à África Central a alta incidência de contatos e a proximidade poderiam fazer de Salvador um ponto de partida de raízes, sementes e mudas de plantas nativas indígenas. $\mathrm{O}$ milho e a mandioca foram largamente disseminados para além das regiões costeiras da África Ocidental e Central. A mandioca foi provavelmente introduzida em Moçambique por iniciativa brasileira e daí espalhou-se pela terra firme, assim como aconteceu com outros gêneros de proveniência brasileira. 
Na segunda metade do século XVIII, barcos de portos brasileiros carregaram uma larga variedade de alimentos para Moçambique: mandioca, milho, batata-doce, feijão, abóbora, caju, goiaba, mamão, abacaxi, e verduras de origem européia. Enquanto a Bahia exportava gêneros alimentícios básicos, as plantas (gengibre, cravo, canela, pimenta) importadas da Índia para a Bahia não constituíram-se em gêneros alimentícios básicos e, apesar do encorajamento oficial, plantadores locais estavam relutantes em alocar terras para o seu cultivo. A contribuição baiana à história da alimentação, especialmente na África, requer mais pesquisas e é uma outra possível dimensão da projeção baiana além do Brasil. Esse legado tem sido duradouro: abacaxi e caju na Índia; batata-doce, milho e amendoim na China; e pimenta-da-guiné na Índia, em Sri Lanka e na China. Mesmo hoje, comese uma feijoada em Goa e há referências a uma pimenta "de Pernambuco". ${ }^{4}$

Observa-se que os historiadores da sociedade e da economia brasileiras têm deixado para os cientistas o estudo da botânica, mas, dada a fertilidade e variedade do solo na Bahia, junto à localização de Salvador enquanto um porto e, assim, impregnado tanto por forças centrífugas quanto centrípetas, a história botânica é um promissor campo para estudos. Darei um exemplo que teve dimensão internacional.

No início do século XIX, chegou ao conhecimento do secretário de estado em Queluz a notícia de que um memorial sobre uma planta chamada "aya-pana", ou "herva milagrosa" havia sido apresentada a um erudito instituto na França. ${ }^{49}$ Natural do Pará, essa planta havia sido cultivada na Bahia. De Salvador, mudas, sementes ou plantas haviam sido enviadas à Île-de-France, onde suas qualidades foram louvadas. O secretário solicitou ao governador que enviasse todos os pés disponíveis para o presidente do Real Erário em Lisboa. Essa planta em discussão era a aiapaína, uma espécie de eupatorium, que os índios brasileiros acreditavam ser um antídoto para veneno de cobra. Isso levanta algumas questóes. Por que era esta planta cultivada na Bahia? Foi uma embarcação francesa com destino às Índias que levou essa planta para a Île-de-France ou foi um capitão baiano que a levou para Moçambique, antes de retornar à Bahia, com sua carga de escravos? Os registros são silenciosos sobre a matéria. 


\section{0 impacto cultural do Brasil no Índico e no Oriente}

Minha sétima linha de indagaçãos diz respeito ao impacto do Brasil sobre os costumes. É bem sabido que o açúcar e o fumo eram os principais produtos de exportação do Brasil no período colonial. Foi o jesuíta Antonil (João Antônio Andreonil) que, em 1711, fez uma distinção entre eles, em termos do impacto que tiveram além Brasil. Residente há 35 anos em Salvador, ele escreveu: "Se o assucar do Brasil o tem dado a conhecer a todos os reynos \& provincias da Europa, o tabaco o tem feito muito afamado em todas as quatro partes do mundo, em as quais hoje tanto se deseja $\&$ com tantas diligencias, e por qualquer via se procura" ${ }^{50} \mathrm{~A}$ cana-de-açúcar cultivada na Bahia era exportada principalmente para a Europa, mas também foi levada como carga em embarcações que saíam de Salvador para a África e a Ásia. A distribuição do fumo da Bahia para a África Central, especialmente, e para a Ásia, via Lisboa e/ou diretamente, já foi discutida. O modo de consumo variava: podia ser mastigado, fumado, tomado em pitadas ou aplicado de modo medicinal. Aqui focalizarei o impacto do fumo - a grande maioria de procedência baiana — nos costumes da África e da Ásia. O fumo exportado para a África era, por determinação régia, de ínfima qualidade. Em geral, as folhas tinham praga, estavam estragadas e velhas, o que levou produtores baianos a desenvolveram a técnica de untar as cordas de fumo com melaço, dando ao fumo um aroma e sabor adocicado. Assim preparadas, as cordas tornaram-se extraordinariamente atraentes ao gosto, precisamente no mercado do qual os baianos importavam o maior número de escravos: o Golfo de Benin. Aí, o fumo baiano difundiu-se largamente como um produto de uso diário, sobretudo para mascar. No Oriente, havia um espectro diferente de gostos. Os atos de fumar e de consumir rapé eram mais comuns do que na África e o consumidor asiático exigia fumo da mais alta qualidade. Ainda se discute sobre a data e a natureza da introdução do fumo na Índia, mas, no século XVI, no Deccan, ele foi associado aos portugueses. Provocou discussão de doutores e eruditos da corte Mughal. O imperador Jahangir proibiu seu uso e Aurangzeb (1659) proibiu seu cultivo. Mas essas ordens imperiais foram ineficazes. $\mathrm{O}$ fumo era largamente cultivado por lavradores indianos. Em Goa, seu consumo tomou várias formas: fumar um cachimbo ou um charuto tornou-se corri- 
queiro, mas o fumo também era encontrado em pó como rapé e em pequenos pedaços, para mascar. Acreditava-se que a fumaça da folha de fumo era remédio eficiente contra ataques convulsivos de crianças. Folhas de fumo eram usadas externamente na cura da inflamação dos testículos. A sua popularidade pode ser inferida do fato de que três das mais importantes línguas da Índia tinham palavras para o fumo: pan ou dhunti (konkani), tambacu (marathi) e tambaku ou surti (hindi). ${ }^{51} \mathrm{Da}$ Índia foi levado para Málaca e China. O historiador inglês Charles Boxer observou que os jesuítas da corte imperial em Beijing afirmaram que nenhum presente era mais apreciado pelo imperador manchu e seus mandarins do que o rapé do Brasil. ${ }^{52} \mathrm{Na}$ China, o fumo era usado, por suas qualidades alegadamente medicinais, como remédio e como tratamento para problemas dos olhos. No Japão, quando introduzido, foi barrado por editos oficiais, que baniram o seu uso; porém, homens e mulheres tornaram-se viciados, fumando a folha em cachimbos de metal. ${ }^{53} \mathrm{Na}$ América do Norte, povos indígenas também tinham um gosto pelo fumo brasileiro, que comerciantes franceses e ingleses trocavam por peles. A Hudson Bay Company mantinha um agente em Lisboa para comprar fumo brasileiro, destinado a esse mercado indígena. Num memorando de 1780, o ex-governador da Bahia, Manuel da Cunha Meneses, observou que o fumo encontrava menos mercado dentro de Portugal, do que "nas três partes do mundo por onde gira.". ${ }^{54}$

\section{Conclusão:}

\section{A presença brasileira no Índico e no Oriente. Um balanço}

Já é tempo de fazermos uma avaliação do que tenho chamado de "a dinâmica” da presença brasileira no Índico e no Oriente. Meu objetivo foi testar a hipótese de existirem aspectos administrativos e comerciais que estabeleceram vínculos entre o Brasil e o Estado da Índia. Esta investigação nos levou a uma reavaliação da historiografia a respeito da Carreira da Índia, revelando a dinâmica de uma presença brasileira importante e também uma dimensão pouco comentada, qual seja, o comércio direto entre Salvador e Rio de Janeiro e os portos do Estado da Índia. Admite-se que relações entre o Estado da Índia e o Estado do Brasil foram fragmentárias. Citamos alguns exemplos referentes a uma projeção brasileira além do Cabo 
da Boa Esperança. Mais pesquisa é necessária, não apenas sobre os contatos comerciais Moçambique-Índia, mas sobre Moçambique, como ponto de convergência e articulação entre o Ocidente (Brasil) e o Oriente (Índia), sobre as relações interculturais, e sobre o papel desempenhado pelos comerciantes Baneanes de Guzerate ao levarem para a Índia mercadorias de proveniência brasileira. ${ }^{55}$ A realidade é que o Brasil deixou poucos traços materiais ou artísticos no Oriente e que produtos comerciais e artísticos orientais da Ásia causaram maior impressão no Brasil do que o inverso. Esse impacto reflete a demanda, no Brasil colonial, por sedas, porcelanas, objetos de marfim e pedras preciosas do Extremo Oriente, e por tecidos, bandejas, verniz de laca, caixas de madeira, chá, pimenta e especiarias da Índia. Em 1758, o Conde dos Arcos, vice-rei de Salvador, escreveu que porcelana era "a droga que mais facilmente se vende nesta terra" ${ }^{56}$

Durante o século XVIII, Salvador e Rio de Janeiro assumiram uma dimensão acentuadamente internacional. Houve muitos visitantes estrangeiros fazendo escala. ${ }^{57} \mathrm{~A}$ vida intelectual cresceu com a presença de estudantes que retornavam de seus estudos na Universidade de Coimbra e divulgavam idéias européias. Houve a importação de livros, predominantemente em inglês, francês e latim. Nem Goa, nem Salvador, nem Moçambique ficaram imunes às repercussões da Revolução Francesa e dos "princípios jacobinos" e "abomináveis princípios franceses". Os ideais e aspirações dos sans culottes ressoaram em Goa e no Estado do Brasil. Salvador e Rio de Janeiro foram pontos de convergência de mercadorias da Europa, África e Ásia. No século XVIII, embarcações inglesas e francesas freqüentaram esses portos. As da Companhia Inglesa das Índias Orientais introduziram em Salvador mercadorias de proveniência européia e indiana. Também embarcações da Companhia Oriental Francesa aportaram. Em 1724, uma embarcação sob o comando do capitão Legat chegou a Salvador, a caminho da ilha de Bourbon e Pondichérry. Menos freqüentes foram barcos da Companhia Ostend. ${ }^{58}$

Havia três áreas bem diferentes, nas quais o Brasil fazia parte de diásporas globais, que incluíam, mas também transcendiam, o Império ultramarino português. Desde o início do século XVI houvera uma emigração forçada de cristãos-novos de Portugal. Em muitos casos, especial- 
mente na Ásia, eles se uniram a comunidades judias já existentes. Nos séculos XVI e XVII houve uma presença de cristãos-novos por todo o Brasil, alguns dos quais engajados no cultivo do açúcar, outros no comércio. Estes cristãos-novos faziam parte de uma diáspora global de famílias judaicas dentro e fora do império português. ${ }^{59}$ Ademais, o contrabando forneceu oportunidades para baianos e outros brasileiros entrarem em contato com ingleses, franceses, holandeses, norte-americanos e hispano-americanos. ${ }^{60}$ Em toda parte existiram dois tipos de comércio, o legal e o clandestino. Os arquipélagos dos Açores e das Madeiras, as Ilhas de São Tomé e Príncipe e os portos na África Central eram pontos de articulação desse tráfico clandestino e legal no Atlântico. De não menor variedade foram os comerciantes com os quais os brasileiros entraram em contato em Moçambique: árabes, franceses, espanhóis de Cuba e de outros portos da América espanhola, escravistas norte-americanos, baneanes de Guzerate e comerciantes muçulmanos. ${ }^{61}$ Salvador e Rio de Janeiro foram portos que assistiram à entrada e saída de produtos que só podem ser estudados num contexto global: o ouro, as especiarias, o fumo e os têxteis. Não há dúvida de que uma pequena proporção da prata e do ouro americano que foi levada para Europa (e pelos espanhóis diretamente de Acapulco para Manila) pelos espanhóis e portugueses foi exportada mais uma vez para o Oriente para efetuar compras, ou disseminada pelos otomanos em troca de mercadorias oriundas da Índia, sobretudo os têxteis. ${ }^{62}$ Fica para pesquisar até que grau o ouro brasileiro, e mesmo as patacas espanholas que entraram no Brasil clandestinamente pelo Rio da Prata, fizeram parte dessa redistribuição de metais preciosos americanos levados para Europa, e também para efetuar compras de especiarias, têxteis e objetos de luxo, introduzidos nos portos brasileiros pelas naus da Carreira da Índia ou por aquelas naus que só transitaram entre o Brasil e a Ásia. Com a mudança da importância comercial e estratégica do Oceano Índico para o Atlântico, e do Estado da Índia para o Brasil - ao lado de fortes comprometimentos da Coroa portuguesa para com o Brasil, mais tarde reforçados por iniciativas comerciais pombalinas —, Salvador e Rio de Janeiro tornaram-se as mais importantes cidades do Império português e capitais sucessivas da mais rica colônia de Portugal. 
Iniciei este artigo referindo-me a dois aspectos da historiografia de impérios multicontinentais: a bifurcação da historiografia e uma historiografia vista através do prisma metropolitano. Espera-se que, nesse sentido, este trabalho tenha fornecido um pequeno corretivo. Além do mais, através do engajamento no comércio intercolonial e da participação no contrabando, os brasileiros não apenas minaram o propósito do sistema mercantilista mas, consistentemente, resistiram a pressões metropolitanas, desenvolvendo uma estratégia de resistência que nem reis nem conselhos metropolitanos puderam vencer. $\mathrm{O}$ fato de que havia flexibilidade e potencial para negociação dentro do sistema colonial sugere ter havido um certo grau de aceitação oficial do status quo. Também se atribui uma postura mais agressiva a brasileiros agindo independentemente da Metrópole e interagindo com outras partes do Império, de maneiras não regulamentadas nem antecipadas pela Metrópole. Houve iniciativas brasileiras no comércio internacional, levando mesmo a contatos e colaboração com mercadores e negociantes europeus, orientais, africanos e com não-cristãos. Mesmo assim, a presença brasileira mais duradoura, no Índico e no Oriente, não foi em termos de comércio, nem do governo secular ou eclesiástico, mas sim em termos de alimentação e de costumes. A história das relaçóes entre o Estado do Brasil e o Estado da Índia é campo fértil para pesquisas que recuperem essa dimensão negligenciada pela historiografia: a presença brasileira no Índico e no Extremo Oriente.

\section{Notas}

${ }^{1}$ Uma forma abreviada deste texto foi apresentada ao Xo Seminário Internacional de História Indo-Portuguesa, na cidade de Salvador, Bahia, em dezembro de 2000. Agradeço ao contra-almirante Max Justo Guedes, aos seus colegas do Patrimônio Histórico e Cultural da Marinha e aos membros da comissão executiva brasileira e da comissão organizadora portuguesa, sobretudo os doutores João Paulo de Oliveira e Costa e Inácio Guerreiro, pelo convite para participar deste seminário magistral.

${ }^{2}$ C. R. Boxer. The Portuguese seaborne empire, 1415-1825. Londres: Hutchinson, 1969. Vitorino Magalhães Godinho. Os descobrimentos e a economia mundial. Lisboa: Livraria Sá da Costa Editora, 1962, 2 vols. . E mais recentemente, Isabel dos Guimarães Sá. Quando o rico se faz pobre: Misericórdias, caridade e poder no império português, 1500-1800. Lisboa: Comissão Nacional para as Comemorações dos Descobrimentos Portugueses, 1997; A. J. R. Russell-Wood. Um mundo em movimento. Os portugueses na África, Ásia e América 
(1415-1808). Lisboa: Difel Editora, 1998; Timothy J. Coates. Degredados e orfãs: colonização dirigida pela Coroa no império português, 1550-1755. Lisboa: Comissão Nacional para as Comemoraçôes dos Descobrimentos Portugueses, 1998.

${ }^{3}$ Fr. João dos Santos. A Ethiopia Oriental, Lisboa: Biblioteca de Clássicos portugueses, 1891; Jean Mocquet. Voyage en Ethiopie, Mozambique et Goa, \& autres lieux d'Afrique \& des Indes orientales (1617). Paris: Editions Chandaigne, 1996.

${ }^{4}$ D. Luís da Cunha. Instruções inéditas de D. Luís da Cunha a Marco António de Azevedo Coutinho. Editores Pedro de Azevedo e António Baião. Lisboa: Academia de Ciências de Lisboa, 1930.

5 José Joaquim da Cunha de Azeredo Coutinho. Ensaio econômico sobre o comércio de Portugal e suas colônias. Lisboa: Academia Real das Ciências, 1828, 3a. edição, Parte 2, cap. $7, \$ 8$.

${ }^{6}$ C. R. Boxer. "The Principal Ports of Call in the Carreira da Índia”. Recueils de la Société Jean Bodin pour l'histoire c omparative des institutions, XXXlll. Les grandes escales (Les temps modernes). Bruxelas: Editions de la Librairie Encyclopédique, 1972, pp. 29-65. Separata. "Moçambique Island and the Carreira da Índia”. In: Studia, 8, Julho 1961, pp. 95-132. A respeito de Salvador, veja também José Roberto do Amaral Lapa. A Babia e a Carreira da Índia. São Paulo: Companhia Editora Nacional, 1968, pp. 327-43.

${ }^{7}$ Amaral Lapa. A Bahia e a Carreira da Índia; Godofredo Filho. "Influências orientais na pintura jesuítica da Bahia”. In: Universitas, 2 (1969), pp. 13-21. A respeito da "projeção" do Brasil no Índico e no Oriente, veja A. J. R. Russell-Wood. "A Brazilian Commercial Presence beyond the Cape of Good Hope, 16th-19th Centuries”, em Pius Malekandathil and T. Jamal Mohammed (orgs.). The Portuguese, Indian Ocean and European Bridgeheads: Festschrift in Honour of Professor K. S. Mathew. Goa: Fundação Oriente, 2001, pp. 191211; e, pelo mesmo autor, "A projeção da Bahia no império ultramarino português", $1 \mathrm{~V}$ Anais do Congresso de História da Bahia. Salvador: Instituto Geográfico e Histórico da Bahia/ Fundação Gregório de Matos, 2001, vol. 1, pp. 81-122.

${ }^{8}$ Carlos Malheiro Dias (ed.). História da colonização do Brasil. Lisboa: Litografia Nacional, 1940, vol. 3, p. 363.

${ }^{9}$ Para uma ótima síntese, veja Max Justo Guedes. "O condicionalismo físico do Atlântico e a expansão dos povos ibéricos”. Studia, 47 (1989), pp. 245-90”; Frédéric Mauro. Le Portugal et l'Atlantique au XVII e siècle (1570-1670). Etude économique. Paris: S.E.V.P.E.N, 1960, pp. 13-27, 70-74; A. J. R. Russell-Wood, Portugal e o mar: um mundo entrelaçado. Lisboa: Assírio e Alvim, 1997.

${ }^{10}$ Fr. António do Rosário. Frutas do Brasil numa Nova, e Ascetica Monarchia. Lisboa: Antônio Pedroso Galrão, 1702, citado por Diogo Ramada Curto. "As práticas de escrita". In: História da expansão portuguesa. Organizado por Francisco Bethencourt e Kurti Chaudhuri. Lisboa: Círculo de Leitores, 1998, vol. 3, p. 421.

${ }^{11}$ Carlos Renato Gonçalves Pereira. História da administração da justiça no Estado da India. Século XVI. Lisboa: Agencia- Geral do Ultramar,1964. Volume 1, pp. 79-80; Stuart B. Schwartz. Sovereignty and Society in Colonial Brazil. The High Court of Bahia and Its Judges, 1609-1751. Berkeley and Los Angeles: University of California Press, 1973. 
${ }^{12}$ Documento de 28 de Dezembro de 1699. Historical Archive of Goa (abreviação, HAG), Livros das monçōes do reino, vol. 63, fol. $411 \mathrm{r}$.

${ }^{13}$ Consulta do Conselho Ultramarino, 21 de Março de 1690; resposta do governador, 23 de Janeiro de 1691, HAG, Livros das monçōes, vol. 55A, fols. 201, 203. Apud Coates, Degredados e orfâs, p. 144 , e nota 165 . A respeito da proposta do governador-geral do Brasil em 1699, veja HAG, Livros das monçôes, vol. 64, fols. 170r-173r). Veja também P. P. Shirodkar, "Brazil's Colonial Administration as Reflected in Goa Archives", Purabhilekh-Puratatva, vol. 8. No. 1, Janeiro/Junho, 1990. Special Issue Índia and Brazil, pp. 26-27. Sobre a Consulta do Conselho de Estado em Goa de 14 de Outubro de 1702, veja Archana Kakodkar, "Source Material for Latin America in Goa (With Special Reference to Brazil)”. In: Essays in: Goan History. Editado por T. R. de Souza. Nova Delhi: Concept Publishing Company, 1989, p. 211 Veja também Philomena Anthony. "Colonial Brazil and Goa: Visible and Invisible Links”, Purabhilekh-Puratatva. Vol. 8. No. 1, Janeiro/Junho, 1990, pp. 82-83 e nota 34.

${ }^{14}$ Eduardo de Castro e Almeida (org.). Inventário dos documentos relativos ao Brasil existentes no Archivo de Marinha e Ultramar de Lisboa. Vol. 2. Bahia, 1763-1786. Rio de Janeiro: Biblioteca Nacional, 1914, no. 10.536-537.

${ }^{15}$ António de Melo e Castro, governador de Moçambique a Rodrigo José de Meneses, governador da Bahia. Moçambique, 15 de Dezembro de 1786. Arquivo Público do Estado da Bahia (abreviação, APB). Correspondência recebida pelo Governo da Bahia. Vol. 197. Governador de Moçambique, doc. 3.

${ }^{16}$ António Manuel de Mo. e Castro ao governador da Bahia, Rodrigo José de Meneses, Moçambique 29 de Novembro de 1786; e de 15 de Dezembro de 1786. APB, Correspondência recebida pelo Governo da Bahia. Vol. 197. Governador de Moçambique, docs. 2 e 3; HAG, Livros das monções, 171B, fols. 568r-72r.

${ }^{17}$ Francisco Adolfo de Varnhagen. História Geral do Brasil. Revisão e notas de Rodolfo Garcia. São Paulo: Ediçōes Melhoramentos, 1975, 8a edição, vol 5, pp. 24396.

${ }^{18}$ Sebastião da Rocha Pitta. Historia da America Portugueza. Segunda edição. Lisboa: Francisco Arthur da Silva, 1880, apêndice ao Livro décimo.

${ }^{19}$ Serafim Leite. "Movimento missionário do Brasil para a Índia”, Boletim do Instituto Vasco da Gama, no. 69. Bastorá, Goa, 1952, pp. 108-118; e o seu artigo, "Luís de Góis. Senhor de engenho no Brasil, introdutor do tabaco em Portugal, Jesuíta na Índia (1504?-1567)”, Brotéria, LXI (Agosto-Setembro, 1955), pp. 146-161. A. P. Ciriaco Fernandes, S.J., Missionários Jesuitas no Brasil no tempo de Pombal. 2a. edição (Porto Alegre: Livraria do Globo, 1941), p. 22. Não consegui consultar estas referências que constam do artigo de Anthony, "Colonial Brazil and Goa: Visible and Invisible Links", pp. 80-81, e notas 28 e 29.

${ }^{20}$ Varnhagen. História Geral do Brasil. Vol. 5, p. 302.

${ }^{21} \mathrm{O}$ estudo mais completo acerca do fumo brasileiro é por Jean-Baptiste Nardi. O fumo brasileiro no periodo colonial. Lavoura, comércio e administração. São Paulo: Editora 
Brasiliense, 1996. Veja também Carl A. Hanson. "Monopoly and Contraband in the Portuguese Tobacco Trade, 1624-1702”. In: Luso-Brazilian Review, 19:2 (1982), pp. 14968; Jean-Baptiste Nardi. "Le commerce du tabac vers l'Inde portugaise du XVII e siècle au début du xixe siècle”, Moyen Orient \& Océan Indien, 6 (1989), pp. 165-74; Roberto do Amaral Lapa. "Dimensōes do comércio colonial entre o Brasil e o Oriente". In: Studia, Vol. 49 (1989), pp. 394-95; Bonifacio Dias. "Impact of Tobacco on Goa (1620-1840)". In: P. P. Shirodkar (org.). Goa: Cultural Trends. Panaji-Goa: Directorate of Archives, Archaeology and Museum, Governo de Goa, 1988, pp. 222-28; Celsa Pinto. Trade and Finance in Portuguese Índia, 1770 1840. Nova Delhi: Concept Publishing Company, 1994, pp. 193-95.

${ }^{22}$ Lapa. “Dimensões do comércio colonial”. In: Studia, 49 (1989), pp. 395-96.

${ }^{23}$ Lapa. A Bahia e a Carreira da India, pp. 253-64, 272-77; Sanjay Subrahmanyam. The Portuguese Empire in Ásia, 1500-1700: A Political and Economic History, Longman: Londres e Nova Iorque, 1993, pp. 183-85.

${ }^{24}$ As naus seguiram as rotas seguintes: Lisboa-Madras com escalas em Pernambuco, Salvador e Rio de Janeiro. Celsa Pinto. "Luso-Brazilian Commerce and the Eastern Littoral of Índia, 1780-1820”, comunicação apresentada ao X Seminário Internacional de História Indo-Portuguesa, Salvador, Dezembro de 2000.

${ }^{25}$ Veja o comentário do Conde de Galvêas a respeito da mortalidade e doenças da tripulação do nau Bom Jesus de Villa Nova durante a viagem de alguns 60 dias de Lisboa para Salvador: "o estrago que fez nestes homens a morte, não proveio tanto das infermidades como da fome e da sede que experimentarão na viagem". Galvêas para o rei. Salvador 3 de Julho de 1748 (APB, "Coleção de ordens régias" vol. 45, doc. 41).

${ }^{26}$ Lapa. A Bahia e a Carreira da India, pp. 292-97; Castro e Almeida. Inventário. Vol. 2. nos. 10.595-99; 10.601-5; 10.611-12; 11.005-7; 10.545; 10.849; 10.856-57; 10.860$66 ; 10.944 ; 11.011-12 ; 11.025-26 ; 11.238 ; 11.491 ; 10.494 ; 11.555 ; 11.625-29 ; 11.737$; 11.754-56. Veja Kakodkar. "Source Material for Latin America in Goa (With Special Reference to Brazil)”, pp. 210-211; Shirodkar. "Brazil's Colonial Administration as Reflected in Goa Archives”, pp. 34-37; Celsa Pinto. “Goa-Brazil Commercial Relations, 1770 1825”, Purabhilekh-Puratatva, 8:1, Janeiro-Junho, 1990, pp. 43-51, 58-61, e o livro dela Trade and Finance in Portuguese Índia, pp. 197-99; Anthony. "Colonial Brazil and Goa", pp. 73-75.

${ }^{27}$ HAG, Livros das monções, vol. 63, fols. 418r-51r; vol. 64, fols.159-162, 164r-v, 16667, 168r-v, 170r-173r.

${ }^{28}$ Lapa. A Bahia e a Carreira da Índia, pp. 262-64, 277.

${ }^{29}$ Celsa Pinto. "Goa-based Overseas and Coastal Trade. 18th-19th Centuries", em Teotonio de Souza (ed.). Goa through the Ages. An Economic History. Nova Delhi: Concept Publishing Company, 1990, vol. 2, pp. 180-81, e a nota 19. 
${ }^{30}$ Veja as referências em Castro e Almeida. Inventário, nota 25 deste ensaio; Kakodkar. "Source Material for Latin America in Goa", pp. 210-211; Shirodkar. "Brazil's Colonial Administration as Reflected in Goa Archives", pp. 34-37.

31 Pinto. "Goa-based Overseas and Coastal Trade. 18th-19th Centuries", pp. 180-81.

32 Pinto. Trade and Finance in Portuguese India.

${ }^{33}$ José António Caldas. Notícia geral de toda esta Capitania da Bahia desde o seu descobrimento até o presente anno de 1759. Edição facsímile: Salvador: Tip. Beneditina, 1951, pp. 525-33; A. J. R. Russell-Wood. "Senhores de engenho e comerciantes", em Francisco Bethencourt e Kirti Chaudhuri (orgs.). História da expansão portuguesa. Lisboa: Círculo de Leitores, 1998, vol. 3, pág. 205-209; João Luís Ribeiro Fragoso. Homens de grossa aventura: acumulação e hierarquia na praça mercantil do Rio de Janeiro (1790-1830). Rio de Janeiro: Arquivo Nacional, 1992.

${ }^{34}$ Veja a valiosa contribuição de Ernst Pijning. "Controlling Contraband: Mentality, Economy and Society in Eighteenth-Century Rio de Janeiro", Tese de doutorado, The Johns Hopkins University, 1997.

${ }^{35}$ Conde de Sabugosa ao secretário do estado, 18 de novembro de 1733. APB, "Coleção de ordens régias”, vol. 29, doc. 169; A. J. R. Russell-Wood. "Colonial Brazil: The Gold Cycle, c. 1690-1750”. In: The Cambridge History of Latin America. Vol. 2. Colonial Latin America. Editado por Leslie Bethell. Cambridge: Cambridge University Press, 1984, pág. 589-93; para fumo, veja Pinto, "Goa-based Overseas and Coastal Trade”, pp. 181 e nota 18.

${ }^{36}$ José Jobson de A. Arruda. O Brasil no comércio colonial. São Paulo: Editora Ática, 1980, pp. 321-23. A respeito do comércio intercolonial nos séculos XVIII e princípios do século XIX, e as ligaçôes de longa distância entre os portos do Brasil, da África oriental, da Índia, e de Macau, veja os artigos por João Fragoso, por Roquinaldo Ferreira, e por Luís Frederico Dias Antunes, na coletânea que abre novas perspectivas sobre o papel desempenhado pelo Brasil no império português: $O$ antigo regime nos trópicos: A dinâmica imperial portuguesa (séculos XV1-XV111), organizado por João Fragoso, Maria Fernanda Bicalho e Maria de Fátima Gouvêa. Rio de Janeiro: Civilização Brasileira, 2001.

${ }^{37}$ Edward A. Alpers. Ivory and Slaves. Changing Pattern of International Trade in East Central África to the Later Nineteenth Century. Berkeley and Los Angeles: University of California Press, 1975), pp. 188-89]; Aurélio Rocha. "Contribuição para o estudo das relaçōes entre Moçambique e o Brasil — século XIX”. Studia, 51(1992), pp. 64-68; José Capela. O escravismo colonial em Moçambique. Porto: Ediçôes Afrontamento, 1993, pp. 193-95.

${ }^{38}$ Alexandre Lobato. Evolução administrativa e econômica de Moçambique, 1752-1763. $1^{\text {a }}$ Parte. Fundamentos da criação do governo-geral em 1752. Lisboa: Agência-Geral do Ultramar, 1957.

${ }^{39}$ Rocha. "Contribuição", pp. 70-72; Ernestina Carreira. "Os últimos anos da Carreira da Índia”, Separata do Carreira da India e as rotas dos Estreitos. Actas do VIII Seminário Internacional de História Indo-Portuguesa. Angra do Heroísmo, 1998, pp. 810-820. 
${ }^{40}$ Joaquim Romero Magalhães. "Os territórios africanos”. In: Bethencourt e Chaudhuri, História da expansão portuguesa, vol.3, pp. 71-73. Leslie Bethell. The Abolition of the Brazilian Slave Trade: Britain, Brazil, and the Slave Trade Question, 1807-1869. Cambridge: Cambridge University Press, 1970, caps. 1-2; Malyn Newitt. A History of Mozambique. Londres: Hurst \& Cia,1995, pp. 248-51; Rocha. "Contribuição", pp. 7585; José Capela. Escravatura. A empresa de saque. O abolicionismo, 1810-1875 (Porto: Afrontamento, 1974).

${ }^{41}$ Alpers. Ivory and Slaves, pp. 211-17.

${ }^{42}$ Pareceres de 1 e 28 de Novembro de 1699. Goa. HAG, Livros das monções do Reino, no. 63 , fols. $418 \mathrm{r}-23 \mathrm{r}$.

${ }^{43}$ Rocha. "Contribuição", pp. 71-75; Alpers, Ivory and Slaves, pp. 127, 211-17; Mary C. Karasch. Slave Life in Rio de Janeiro, 1808-1850. Princeton: Princeton University Press, 1987, pp. 13-15, 21-25, inter alia; João Luís Fragoso. Homens de grossa aventura: acumulação e hierarquia na praça mercantil do Rio de Janeiro (1790-1830). Rio de Janeiro: Arquivo Nacional, 1992, pp. 179-82, 262-63.

${ }^{44}$ George D. Winius. "Portugal's Shadow Empire in the Bay of Bengal”. In: George D. Winius (org.). Portugal, The Pathfinder. Journeys from the Medieval toward the Modern World, 1300-ca. 1600. Madison: Seminary of Medieval Studies, 1995, pág. 247-68; A. J. R. Russell-Wood. "Os portugueses fora do império". In: Bethencourt e Chaudhuri (orgs.). História da expansão portuguesa. Vol. 1 (1998), pp. 256- 65.

${ }^{45}$ Pierre Verger. Flux et reflux de la traite des nègres entre le Golfe de Bénin et Bahia de Todos os Santos. Paris: Mouton \& Co., 1968, sobretudo os capítulos 12 e 16.

${ }^{46}$ José Capela. O escravismo colonial em Moçambique, pp. 195-97; e, do mesmo autor, Donas, senhores, e escravos na Zambésia. Porto: Ed. Frontamento, 1996; Alpers. Ivory and Slaves, pp. 127.

${ }^{47}$ Lapa. A Bahia e a Carreira da Índia, pp. 51-81 e apêndice 1; C. R. Boxer, Salvador de Sá and the Struggle for Brazil and Angola, 1602-1686. Londres: The Athlone Press, 1952, pp. 308-9; F. Borges de Barros. Novos documentos para a história colonial. Salvador, 1931, pp. 23-27. A respeito de uma tal construção, veja a ordem do Conde de Galvêas para o provedor mor , 7 de Fevereiro de 1738, e o despacho do provedor mor de 8 de Fevereiro de 1738 (APB, "Coleção de ordens régias”, Vol. 57, fols. 298-99; vol. 58, fol. 129r; e também Vol. 34, doc. 24. Refere-se à construção de uma nau de 60 peças na ribeira de Salvador, a custo da fazenda real, e destinada para a Carreira da Índia.

${ }^{48}$ Russell-Wood. Um mundo em movimento, pp. 227-76.

${ }^{49}$ Secretário do estado ao governador, 4 de Outubro de 1802 (APB, "Coleção de ordens régias, Vol. 100, fol. 81).

${ }^{50}$ André João Antonil. Cultura e opulência do Brasil por suas drogas e minas. Comentário crítico por Andrée Mansuy. Paris: Institut des Hautes Etudes de l'Amérique Latine, 1968, segunda parte, capítulos 1 e 2 .

${ }^{51}$ Bonifacio Dias. "Impact of Tobacco on Goa", 222-25; e "Tobacco Trade in Goa, 16001850 A.D.”. In: B. S. Shastry (org.). Goan Society through the Ages. Goan University 
Publication Series No. 2. Nova Delhi: Ásian Publication Services, 1993, 178-85; Irfan Habib, The Agrarian System of Mughal Índia, 1556-1707. Nova Iorque: Ásia Publishing House, 1963, pp. 45-46 e notas, e p. 94.

52 Boxer. Salvador de Sá, p. 384, nota 79.

${ }^{53}$ Maria Helena Mendes Pinto. Biombos Namban. Lisboa: Museu Nacional de Arte Antiga, 1988, p. 14 e ilustrações.

${ }^{54}$ Manuel da Cunha Meneses. Lisboa 12 de Agosto de 1780, Castro e Almeida, Inventário, Vol. 2, no. 10.653 .

${ }^{55}$ Michael N. Pearson. Port Cities and Intruders. The Swahili Coast, India, and Portugal in the Early Modern Era. Baltimore: The Johns Hopkins University Press, 1998, pp. 129-54; Michael N. Pearson. "Goa-based Seaborne Trade, 17th-18th Centuries”, in: Teotonio de Souza. "Goa Through the Ages", in: An economic History, vol. 2, pp. 146-75; e Celsa Pinto. "Goa-based Overseas and Coastal Trade" idem, pp. 186-91, e seu livro Trade and Finance in Portuguese Índia, pp. 111-117,163-83. Veja P. P. Shirodkar. "Índia and Mozambique: Centuries-Old Interaction”, Purabhilekh-Puratatva, 6:1, Janeiro-Junho 1988. Special Issue. Índia and Mozambique, pp. 35-62.

${ }^{56}$ APB, "Coleção de ordens régias", vol. 58, fols. 154r-202v, 275-307v; Conde de Arcos ao rei, Salvador, 28 de Maio de 1758, vol. 60, fols. 150r-v; veja também Eldino da Fonseca Brancante. O Brasil e as louças da Índia. São Paulo: Tip. Elvino Pocai, 1950.

${ }^{57}$ Moema Parente Augel. Visitantes estrangeiros na Bahia oitocentista. São Paulo: Editora Cultrix, 1980, pp. 23-57.

${ }^{58}$ APB, "Coleção de ordens régias", vol. 9, doc. 32; vol. 19, docs. 61, 78, 79; vol. 21, doc. 110; vol. 23, doc. 43.

${ }^{59}$ James C. Boyajian. Portuguese Trade in Asia under the Habsburgs, 1580-1640. Baltimore: The Johns Hopkins University Press, 1993; Russell-Wood. O mundo em movimento, pp. 164-7.

${ }^{60}$ Azeredo Coutinho. Ensaio economico sôbre o comércio de Portugal, parte 2, cap. 1,\$10$16]$

${ }^{61}$ Alpers. Ivory and Slaves, p. 209; Rocha. "Contribuição", p. 74.

${ }^{62}$ Sushil Chaudhury e Michel Morineau (ed.). Merchants, Companies and Trade. Europe and Asia in the Early Modern Era. Cambridge: Cambridge University Press 1999, pp. 111 12 e nota 57; pp. 135, 302.

\section{Resumo}

O propósito deste ensaio - que busca revisar e complementar a historiografia sobre o tema - é oferecer uma perspectiva brasileira do comércio para além do Cabo da Boa Esperança, examinar a presença brasileira no Estado da India e, ainda, resgatar as dinâmicas iniciativas dos comerciantes brasileiros, bem como destacar o importante 
papel dos portos brasileiros. Salienta a importância de Moçambique como ponto de convergência e de articulação entre o Oriente e o Ocidente, não apenas em termos comerciais mas também do ponto de vista cultural, referindo-se à contribuição brasileira aos costumes è dieta dos habitantes da África Oriental, da Índia, da China e do Japão.

\section{Abstract}

This is an essay in compensatory and revisionist history whose purpose is to look at the Portuguese seaborne empire from a Brazilian and not a Portuguese metropolitan perspective, to examine the Brazilian presence and influence not in regions bordering the Atlantic but in the Estado da India, and to attribute to Brazilian merchants greater initiative and to Brazilian ports a more important role than is usually the case in the historiography by their engaging in commerce beyond the Cape of Good Hope. The role of Mozambique as a point of convergence and of articulation between East and West is emphasized not only in commercial terms but in the context of intercultural exchanges. Reference is made to the lasting legacy of Brazil to East Africa, India, China and Japan in terms of customs and diet. 